\title{
THE SUPREME COURT, THE BILL OF RIGHTS AND THE STATES
}

\section{By John Raeburn Green $\dagger$}

A study of the judicial process as revealed in the opinions of the Supreme Court of the United States relating to enforcement of the guarantees of the Bill of Rights against the states must deal largely with recent decisions. The first such enforcement of any of the First Amendment freedoms did not occur until 1927, ${ }^{1}$ when the Fourteenth Amendment was well into its sixth decade. As late as 1922 the Court still said that "the Constitution of the United States imposes upon the states no obligation to confer upon those within their jurisdiction . . . the right of free speech . . . neither the 14th Amendment nor any other provision of the Constitution of the United States imposes upon the states any restriction about 'freedom of speech." " 2

The field presents questions of the highest constitutional importance, dealing simultaneously with the relation of government to the individual and with the relation of national power to state power under our federal system, from each of which opposing considerations are drawn and placed in conflict. The struggle is an ancient one, whose intensity has increased as a rising tide of liberty has at last submerged and swept away many long-impregnable battlements of state power to deny individual rights and freedoms, and is now surging-with only short remissions-around those which still remain.

The struggle with respect to the rights of the accused in criminal prosecutions has been surveyed elsewhere. ${ }^{3}$ The sections following deal chiefly with the First Amendment freedoms.

† A. B., 1914, Westminster College; LL. B., 1917, Harvard University; member of the St. Louis Bar.

In the preparation of this paper, three previous articles by the author, entitled Liberty Under the Fourteenth Amendment, appearing in 27 WASE. U. L. Q. 497 (1942), 28 WASH. U. L. Q. 251 (1943), and 43 M ICH. L. REV. 437 (1944), have been drawn upon. In these articles the decisions through the 1943 Term are considered on the merits.

The author wishes to express his indebtedness to Milton I. Goldstein, Esq., of the St. Louis Bar, for great help in the revision of this article.

1. Fiske v. Kansas, 274 U. S. 380 (1927). This was also the first successful invocation in the Court of any of the guarantees of the First Amendment against either a state or the United States. A by-product of enforcing the First Amendment freedoms against the states has been that the Court is now for the first time enforcing them against the United States also. See National Labor Relations Board v. Virginia Electric \& Power Co., 314 U. S. 469 (1941) ; Busey v. District of Columbia, 319 U. S. 579 (1943), discussed note 14 infra.

2. Prudential Insurance Company v. Cheek, 259 U. S. 530, 538, 543 (1922).

3. Green, The Bill of Rights, the Fourteenth Amendment and the Supreme Court, 46 MicH. L. Rev. 869 (1948). 


\section{The Background}

Our constitutional history is largely the result of the compulsion of circumstance, to do what we would rather not do, to change when we would remain as we were. There was irony in the fact that those who considered that government best which governed least, should have been compelled to set up not one but two sovereignties over the individual. The power of the states was well established, being indeed the only power existing at that moment; and it was not only natural but prudent to direct the guarantees of individual liberty first to the new national power, rather than to that of the states. Yet it should not be forgotten that, in spite of this consideration, Madison's draft of the Bill of Rights, submitted to the First Congress on June 8, 1789, included the following: "No state shall violate the equal rights of conscience, or the freedom of the press, or the trial by jury in criminal cases." " $\mathrm{He}$ urged, "I cannot see any reason against obtaining even a double security on these points . . . because it must be admitted, on all hands, that the State Governments are as liable to attack these invaluable privileges as the General Government is, and therefore ought to be as cautiously guarded against." The Select Committee to which Madison's draft was referred added to it "freedom of speech." When this Amendment was opposed in debate in the House, ${ }^{5}$ Madison supported it with great vigor, saying that he "conceived this to be the most valuable Amendment in the whole list. If there was any reason to restrain the Government of the United States from infringing upon these essential rights, it was equally necessary that they should be secured against State Governments. . . ."6

The Amendment was passed by the House, ${ }^{7}$ but to Madison's great disappointment, was rejected by the Senate, the House later concurring. ${ }^{8}$ The exclusion was deliberate, and the intention of Congress was clear, both from the rejection and because the Bill of Rights in terms restricted only the federal government. Yet the vitality of the belief that the Constitution could not have left these fundamental

4. 1 Annals of Cong. 435 (1789).

5. Thomas Tudor Tucker of South Carolina argued: "It will be much better . . . to leave the State Governments to themselves, and not interfere with them more than we already do; and that is thought by many to be rather too much." Id. at 755 .

6. Ibid.

7. As passed by the House the Amendment read: "The equal rights of conscience, the freedom of speech or of the press, and the right of trial by jury in criminal cases, shall not be infringed by any State." Ibid. For a reference to contemporary newspaper publications favoring the Amendment, see Warren, New Light on the History of the Federal Judiciary Act of 1789, 37 HARv. L. REv. 49, 121 (1923).

8. Mr. Charles Warren's account of all this is admirable. Warren, The New "Liberty" Under the Fonrteenth Amendment, 39 HARv. L. REv. 431, 433-435 (1926). For additional details, see CurTis, LIONS UNDER THE THRone 267-269 (1947). 
liberties wholly unprotected against state denial was so great as to suggest that protection against the states was an essential part of our constitutional scheme. Commencing in $1833^{\circ}$ and continuing as late as $1913,{ }^{10}$ the contention that the Bill of Rights (unaided by the Fourteenth Amendment) restricted the powers of the states was pressed upon the Court over and over again, and uniformly rejected by it.

Mr. Charles Warren has attributed the persistence of this struggle to the "ignorance, incorrigible optimism, or desire for delay" of counsel for defendants "(chiefly in murder and other criminal cases)." 11 This explanation seems hardly adequate. Considering all the circumstances, it would be more reasonable to attribute the continued recurrence of these hopeless appeals to the intensity of the feeling that the Constitution must somehow protect these rights and liberties against all governmental invasion, and to the urgency of the need for such protection against the states. The great number of these cases (plus, after 1868, cases based on the Fourteenth Amendment) was itself sufficient to demonstrate that Madison's prophetic argument, "the State Governments are as liable to attack these invaluable privileges as the General Government is," was a considerable understatement. It is now evident that denial of the First Amendment freedoms is attempted far more often by the states (including their municipalities, counties, school boards and courts) than by the federal government. In the twenty-four years from 1925 (when Gitlow v. People of New York $^{12}$ first made comparison possible) to 1949, the Court's opinions deal with sixty-seven claims of state denial, of which "no less than forty-one were sustained, ${ }^{13}$ but with only nineteen claims of federal denial, two ${ }^{14}$ of which were sustained..$^{15}$

9. Barron v. Baltimore, 7 Pet. 242 (U. S. 1833).

10. Ensign v. Pennsylvania, 227 U. S. 592 (1913).

11. Warren, supra note 8 , at 436 , concluding his collection of the cases.

12. 268 U. S. 652 (1925).

13. Several of the remaining twenty-six were dismissed or remanded for procedural reasons, and one case in which the claim was denied was subsequently overruled.

14. Of these two, it must be said that only National Labor Relations Board v. Virginia Electric \& Power Co., 314 U. S. 469 (1941), presented a real case of federal invasion, and the holding there was conditional. Busey v. District of Columbia, 319 U. S. 579 (1943), involved what was essentially a municipal ordinance, although it was an Act of Congress.

15. The cases through the 1943 Term are listed and tabulated in Green, Liberty Under the Fourteenth Amendment, 27 WASH. U. L. Q. 497, 536 n. 194 (1942), 28 WAsH. U. L. Q. 251, 252-253 nn. 9, 10 (1943), 43 MICH. L. REV. 437, 441 n. 14 (1944). The cases in the 1944, 1945, 1946, 1947, and 1948 (through April 1, 1949) Terms are:

State (claim sustained) : Thomas v. Collins, 323 U. S. 516 (1945); Marsh v. Alabama, 326 U. S. 501 (1946); Tucker v. Texas, 326 U. S. 517 (1946); Pennekamp v. Florida, 328 U. S. 331 (1946); Craig v. Harney, 331 U. S. 367 (1947); Illinois ex rel. McCollum v. Board of Education, 333 U. S. 203 (1948); Winters v. New York, 333 U. S. 507 (1948); Saia v. New York, 334 U. S. 558 (1948). 
With the adoption of the Fourteenth Amendment in 1868, there became available for the first time reasonable bases on which to build the claim to constitutional protection. The contention was madeunsuccessfully, but always with the support of a vigorous minority of the Court-for some fifty years that these liberties were privileges or immunities, protected by that clause of the Amendment; and, commencing in $1907,,^{18}$ that freedom of the press was embraced within the "liberty" guaranteed by the due process clause. The first victory was won in 1925 when Gitlow v. People of New York ${ }^{17}$ established the protection for freedom of speech and of the press, as guaranteed by the First Amendment, as integral elements of the "liberty" which the due process clause guards against state denial. ${ }^{18}$ The Court in 1937 included in "liberty" the right peaceably to assemble, ${ }^{10}$ and, after displaying remarkable caution to avoid the decision for some years, ultimately extended the same protection to the free exercise of religion in $1940 .^{20}$ The protection of the right to petition for a redress of

State (claim dismissed or remanded for procedural reasons): Alabama State Federation of Labor v. McAdory, 325 U. S. 450 (1945); C. I. O. v. McAdory, 325 U. S. 472 (1945); In re Summers, 325 U. S. 561 (1945); American Federation of Labor v. Watson, 327 U. S. 582 (1946) ; Everson v. Board of Education, 330 U. S. 1 (1947); Rescue Army v. Municipal Court of Los Angeles, 331 U. S. 549 (1947) Gospel Army v. Los Angeles, 331 U. S. 543 (1947) ; Musser v. Utah, 333 U. S. 95 (1948) ; Cole v. Arkansas, 333 U. S. 196 (1948); Parker v. Illinois, 333 U. S. 571 (1948) ; Lincoln Federal Labor Union v. Northwestern Iron \& Metal Company, 335 U. S. 525 (1949); Whitaker v. North Carolina, 335 U. S. 525 (1949); American Federation of Labor v. American Sash \& Door Company, 335 U. S. 538 (1949); Kovacs v. Cooper, 336 U. S. 77 (1949) ; International Union U. A. W., A. F. of L., Local 232 v. Wisconsin Employment Relations Board, 336 U. S. 245 (1949).

Federal (clain dismissed in all): Associated Press v. United States, 326 U. S. 1 (1945) ; Bridges v. Wixon, 326 U. S. 135 (1945) (decided for claimant on other grounds); May Dept. Stores Co. v. National Labor Relations Board, 326 U. S. 376 (1945) ; Hannegan v. Esquire, Inc., 327 U. S. 146 (1946) (decided for claimant on construction of statute); Mabee v. White Plains Pub. Co., 327 U. S. 178 (1946) ; Oklahoma Press Pub. Co. v. Walling, 327 U. S. 186 (1946); Girouard v. United States, 328 U. S. 61 (1946) ; Cleveland v. United States, 329 U. S. 14 (1946); United Public Workers v. Mitchell, 330 U. S. 75 (1947) ; United States v. Petrillo, 332 U. S. 1 (1947); Donaldson v. Read Magazine, Inc., 333 U. S. 178 (1948); United States v. Paramount Pictures, Inc., 334 U. S. 131 (1948).

Memoranda cases have not been included in these tabulations.

It will be observed that the Court has dealt with more claims of federal abridgment in the last five years than in the preceding nineteen; but that none of the recent claims have been sustained.

16. Patterson v. Colorado, 205 U. S. 454 (1907).

17. 268 U. S. 652 (1925).

18. While Fiske v. Kansas, 274 U. S. 380 (1927), was the first decision actually extending the protection, this and succeeding cases have been rested upon the authority of the ambiguous dictum in Gitlow v. People of New York, 268 U. S. 652, 666 (1925).

As is well known, originally "liberty" had meant simply freedom from physical restraint. The expansion to include these freedoms resulted from an earlier expansion to include liberty of contract. See Green, Liberty Under the Fourteenth Amentment, 27 WASE. U. L. Q. 497, 505-514 (1942).

19. De Jonge v. Oregon, 299 U. S. 353 (1937). See also Herndon v. Lowry, 301 U. S. 242 (1937); Hague v. CIO, 307 U. S. 496 (1939).

20. Cantwell v. Connecticut, 310 U. S. 296 (1940). 
grievances, exercised independently of any assembly, was achieved in $1941 ; 21$ and the incorporation of the First Amendment in the due process clause of the Fourteenth was completed in 1947, almost unnoticed, by the dictum that the prohibition of the establishment of religion ran against the states. ${ }^{22}$

While the First Amendment freedoms were thus, one by one, being brought within the concept of liberty, the Court simultaneously considered, and in some cases appeared to give protection to, the rights which the Bill of Rights guarantees to one suspected, accused or convicted of crime, including the privilege against self-incrimination and the right against double jeopardy guaranteed by the Fifth Amendment, and the rights of confrontation with witnesses and assistance of counsel, guaranteed by the Sixth. The effect upon this situation of the fair trial rule, recently developed by the Court as a part of due process, and turned against these rights for the first time in Betts $v$. $B r a d y,{ }^{23}$ was to leave their position obscure (particularly in the case of the right to the assistance of counsel), and to precipitate the most violent clash of the opposing forces in three five-to-four decisions handed down on the last day of the 1946 Term. $^{24}$

In the Court's decisions of the last nine years, the influence of five former Justices-Harlan, Holmes, Brandeis, Sutherland and Cardozo-is easily discerned. The influence of Mr. Justice Harlan, "the Great Dissenter," and of Mr. Justice Sutherland, is wholly libertarian, and their support of that side extends through the whole field of conflict. Mr. Justice Holmes' influence has, of course, been profound in support of freedom of speech, but elsewhere has been exerted on both sides of the struggle. ${ }^{25} \mathrm{Mr}$. Justice Brandeis has done as much for freedom of expression as Mr. Justice Holmes, in a different way, but beyond that has been neutral; while Mr. Justice Cardozo's is the force which turned the tide against the rights of the accused in

21. Bridges v. California, 314 U. S. 252, 277 (1941).

22. Everson y. Board of Education, 330 U. S. 1 (1947). In 1948 this was squarely held. Illinois ex rel. McCollum v. Board of Education, 333 U. S. 203 (1948). While Mr. Justice Reed dissented in the McCollum case, he did not do so on, the ground that the First Amendment's prohibition of the establishment of religion was not included in the "liberty" which is guaranteed by the due process clause of the Fourteenth Amendment. Professor Corwin has recently urged that the prohibition is not a part of "liberty" unless "establishment of religion" be given an application which carries with it invasion of someone's religious liberty. See Corwin, The Supreme Court as National School Board, 23 THOUGHT 665, 677 et seq. (1948).

23. 316 U. S. 455 (1942).

24. Adamson v. California, 332 U. S. 46 (1947); Gayes v. New York, 332 U. S. 145 (1947); Foster v. Illinois, 332 U. S. 134 (1947). These cases are discussed at pp. $638-639$ infra.

25. See discussion of "the paradox of the Holmes tradition" in Barnett, Mr. Justice Murphy, Civil Liberties and the Holmes Tradition, 32 CoRN. L. Q. 177, 179184 (1946). 
criminal prosecutions. The influence of Mr. Justice Sutherland has seldom been adequately recognized, and it is worth while to recall the words of Mr. Chief Justice Stone:

The time will come when it will be recognized, perhaps more clearly than it is at present, how fortunate it has been for the true progress of the law that, at a time when the trend was in the opposite direction, there sat upon this Bench a man of stalwart independence, and of the purest character who, without a trace of intellectual arrogance, and always with respectful toleration for the views of colleagues who differed with him, fought stoutly for the constitutional guarantees of the liberty of the individual. As one of those who sometimes differed, I shall ever hold in grateful remembrance this contribution of Justice Sutherland to the work of the Court. ${ }^{26}$

Even before the field of liberty had attained its present expanse, it was observed that the due process clause opened the door to the widest differences of opinion, its words being "so unrestrained by their intrinsic meaning as well as by their history and traditions, that each Justice is impelled to depend upon his own controlling conceptions, which are in turn bound by his experience and imagination, his hopes and fears, his faith and doubts." 27 Consideration of these opinions, if it is to be effective, must, like the opinions themselves, take into account much more than texts and precedents. One may also plead Mr. Justice Brewer's admonition, that it is "a mistake to suppose that the Supreme Court is either honored or helped by being spoken of as beyond criticism," and that, while "many criticisms may be, like their authors, devoid of good taste . . . better all sorts of criticism than no criticism at all." 28 From the opinions of the Court it appears that the limits of good taste are not so narrow as to eliminate all vigor. ${ }^{29}$

\section{The Advance of Federal Power}

In its essence the conflict mirrored in these cases is simply one phase of the great struggle between the federal government and the

26. 323 U. S. xx-xxi (1944). 126 (1927).

27. Frankfurter, Mr. Justice Holmes and the Constitution, 41 HARv. L. REv. 121,

28. See the address by Mr. Justice Brewer, Lincoln Day, 1898, Govermnent by Injunction, 15 NAT. CoRP. REP. 848, 849 (1898), quoted by Mr. Justice Frankfurter in Mr. Justice Holmes and the Constitution, 41 HARV. L. REv. 121, 164 (1927), again in Mr. Justice Holares and the Supreare Court 94 (1938), and still later in his dissenting opinion in Bridges v. California, 314 U. S. 252, 289 (1941). Mr. Justice Jackson quoted it in The STRUgGle For JuDICIAL Suprearacy xviii (1941). In the Bridges case, Mr. Justice Frankfurter added that "judges must be kept mindful of their limitations and of their ultimate public responsibility by a vigorous stream of criticism expressed with candor however blunt." Bridges v. California, supra at 289.

29. Cf. Mr. Justice Jackson, dissenting in Securities and Exchange Commission v. Chenery Corp., 332 U. S. 194, 209 (1947). This is cited simply as the latest example of the vigorous expression which has had a long history in the Court. 
states for power-that is, power over the individual-and the individual's resistance to both. The other phases of the struggle may affect this one. Some consideration should be given to the relation of the advance of federal power and its progressive exclusion of state power, in social and economic fields, to the enforcement of the Bill of Rights against the states.

Less than one hundred years ago, the impact of power, whether federal or state, upon the individual was insignificant. The enormous development of both federal and state power has been due to our transformation into an industrial society and in particular to the development of communications and transport. As Mr. Justice Frankfurter put it, in 1930:

Following the Civil War there was an almost magical industrial growth. Radiating railroads are the muscles which have pulled into an articulate body the detached and sprawling members of our great domain. A vast nervous system of telephones and telegraphs and wireless has, on the surface at least, electrified the scattered regions of the country into a self-conscious whole. The concentration of life in big cities has made of them working ganglia of the nation. A relatively homogeneous population with restricted disparities of wealth, has been transformed into a cumbersome democracy drawn from many peoples, containing some forty million wage earners, with great inequalities in wealth and increasing pressure of conflicting interests. Vast physical forces have produced great social changes. They have been fertilized by theories concerning man and society. Radical ideas let loose by the American Revolution, the French Revolution, the revolutionary movements of 1848 , have slowly but profoundly affected men's desires and their demands upon government. All this ferment has been greatly reinforced by the dissolving consequences of the World War. ${ }^{30}$

This was the cause of the expansion of the federal government's exertions of power "beyond all recognition." At the same time it produced an almost equally great expansion in the exercise of power by the states. ${ }^{31}$ But as the two sovereignties, thus extending their power simultaneously, have brought more and more individual activity under regulation or prohibition, the area of free individual activity has diminished. Since 1930, the New Deal and the Second World War have induced an acceleration of the expanding process, and the collision of federal and state power has necessarily (the area available for expansion being now so reduced) been much more frequent than be-

30. Frankfurter, The Public and Its Government 23-24 (1930).

31. The processes are admirably described in FRANKFURTER, id. at 8-31. 
fore. In these collisions the federal power has triumphed, and its triumph has been sealed by the approval of the Court. The doctrine of "occupation of the field" has been combined with the much broader definition of interstate commerce now applied by the Court to the new exercises of federal power, to produce a situation where the commerce clause has perhaps replaced due process as the principal constitutional basis for invalidating state exercise of power. ${ }^{32}$ The commerce clause has become a limitation upon the power of the states, even in absence of action by Congress. ${ }^{33}$ State legislation with respect to local and intra-state activities is now struck down even though there is no actual conflict whatever; ${ }^{34}$ and "the expansion of our industrial economy has inevitably been reflected in the extension of Federal authority over economic enterprise and its absorption of authority previously possessed by the states." 35 And great fields of power have been removed from the states, not by Congress but by the Court alone. ${ }^{36}$

Except in that the Court has occasionally seemed to have gone rather far in acting where Congress appears not to have acted, to have used perhaps excessive ingenuity in finding in Congressional legislation what was rather difficult to find, the decisions cannot fairly be criticized. The advance of federal power, however much we may regret it, seems to have been in the main as inevitable as the advance of science which produced it.

But precisely the same forces that caused these expansions of power, and when collisions occurred, the supremacy of federal power, are at the same time responsible for the increased urgency of safeguarding against state denial the rights and liberties guaranteed by the Bill of Rights. In a country constantly becoming smaller and more compact, the new vitality given to the First Amendment freedoms by the decisions which have in the last twenty years enforced them against the states has been an unmistakable factor in off-setting and to an extent easing the pressure of increasing power on the individual. Our national unity is increased by the acceptance of exercises of power, which the individual would not accept so easily if he

32. See Note, "Occupation of the Field" in Conmerce Clanse Cases, 1936-1946: Ten Years of Federalism, 60 HARv. L. REv. 262 (1946).

33. Morgan v. Virginia, 328 U. S. 373 (1946) ; Southern Pacific Co. v. Arizona, 325 U. S. 761 (1945).

34. Rice v. Santa Fe Elevator Corp., 331 U. S. 218 (1947) ; Bethlehem Steel Co. v. New York State Labor Relations Board, 330 U. S. 767 (1947).

35. A. B. Kirschbaum Co. v. Walling, 316 U. S. 517, 520 (1942).

36. United States v. South-Eastern Underwriters Ass'n, 322 U. S. 533 (1944). But the McCarran Act subsequently legalized state regulation of insurance, signifying a temporary return of power to the states. 59 STAT. 33 (1945), 15 U. S. C. \$1011 (1946). 
were not still allowed the freest criticism both of the power and of its application. The uniformity established by the new liberty has also been most valuable in this regard. In the first place, it has brought the First Amendment freedoms to states which previously lacked some of these guarantees. While most (but not all) state constitutions have safeguards for freedom of speech and of the press and for religious freedom, the provisions differ widely, and even when they were couched in identical terms, state courts had found them capable of a wide variance in construction. The forty-one decisions which have enforced these freedoms against the states were cases in which state courts had found nothing which offended the appropriate state constitutional provisions. There was never any perceptible advantage in having identical statutes held (as were the Service Letter Statutes) in Georgia, Kansas and Texas to be unconstitutional deprivations of free speech, and in Missouri not to be. ${ }^{37}$ Since 1927, freedom of speech and of the press have begun to have the same meaning, without degree or difference, in every State of the Union. The standard applied is now identical everywhere. Secondly, this uniformity is itself increased by the enlargement of the freedoms which has resulted from the vitalization which has occurred in applying them to the states. The field in which governmental action, whether federal or state, may constitutionally operate to restrict freedom of speech and of the press, or of religion, lies somewhere between zero and the line established in the cases since these freedoms were first included in the liberty protected by the Fourteenth Amendment. Each time the outer limit of this field is compressed, as by the clear and present danger rule, ${ }^{38}$ or by the bar against subsequent punishment, ${ }^{39}$ the field for state action is accordingly narrowed; so that not only do the freedoms become greater, but so also does their uniformity throughout the states. The result has been demonstrated in the case of the First Amendment freedoms. A common freedom of expression contributes to national unity in the same way that a common language does. It would, indeed, be surprising if it should be considered that uniformity in these fundamental rights is not advantageous, when (again because of the development of communications and transit) uniformity in many fields of state statute law and state common law has been so arduously sought.

37. Wallace v. Georgia C. \& N. Ry., 94 Ga. 732, 22 S. E. 579 (1893) ; Atchison T. \& S. F. Ry. v. Brown, 80 Kan. 312 102 Pac. 459 (1909) ; St. Louis S. W. Ry. v. Griffin, 106 Tex. 477, 171 S. W. 703 (1914) ; Cheek v. Prudential Ins. Co., 192 S. W. 387 (Mo. 1916).

38. Adopted by the Court as the test for abridgment of freedom of speech and of the press, and freedom of assembly, in Herndon v. Lowry, 301 U. S. 242 (1937).

39. See Near v. Minnesota, 283 U. S. 697 (1931). 
These considerations apply with almost equal force to some, at least, of the rights guaranteed by the Fourth, Fifth, Sixth and Eighth Amendments. It has become increasingly difficult to view diversities in the invasion by the states of these rights with the equanimity with which they were once regarded. ${ }^{40}$ Most of us cross state lines a thousand times more often than our grandfathers did. In a single afternoon one may now drive through half a dozen states, exposing himself to the hazard of a manslaughter charge at every mile. The rights of one accused of crime, while identical throughout the land in federal courts, may differ in the courts of each state he enters. Thus, when Illinois, for example, denies the right to counsel, ${ }^{41}$ it does not deny it simply to its own citizens and residents, who, if a majority of them dislike the situation, may change it, but to any one within its limits, however transiently. If it were not well known, no more than an examination of the opinions in this field would indicate that a large proportion of all criminal convictions are of indigent persons in transit, not citizens or residents of the prosecuting state. To which it must be added that not only are such persons precisely those most in need of the rights guaranteed by these Amendments, most helpless without them; but that they are also those to whom the rights will, as a rule, be most rigorously denied.

Aside from these direct considerations, the expansion of governmental power has in itself greatly increased the urgency of enforcing the Bill of Rights against the states. It is precisely because it has now become necessary for government to restrict, regulate, abridge or destroy the individual's freedom to work, to employ, to farm, to travel, to buy, to sell, to rent, to engage in business and even to eat, as he pleases, that it becomes imperative not only to preserve but to enlarge his right to speak his mind freely regarding government and its restraints. The individual has much more to criticize than ever before, he has much more to say, and the necessity of his saying it has now become a consideration of the highest social importance. It must also be observed that whereas a century ago it was difficult to commit a crime without being conscious of it, without infraction of a known and simple moral law, now a man no more than reasonably active in his own business may in a single day, quite unwittingly and in all good conscience, render himself liable to criminal prosecution for half a dozen offenses, federal and state. Virtually all of the new restraints upon individual freedom are enforcible by criminal prosecutions. The

40. See Missouri v. Lewis, 101 U. S. 22, 31 (1880).

41. As it did until September 1, 1948, when Rule 27-A of the Supreme Court of Illinois became effective. See 400 Iil. following 21 (1948). 
vast increase in the number of criminal prosecutions has tended to make the prosecuting process one of mass production, in which there is constant pressure to abridge the rights of the accused. And the rights of the accused have a direct relation to the First Amendment freedoms, for whose suppression criminal prosecution has always been the most common and most effective instrument. Mr. Justice Black has, indeed, recently suggested that these rights were included in the Bill of Rights because it was necessary to protect them in order to protect the First Amendment freedoms to which they were primarily auxiliaries. ${ }^{42}$

We have thus the spectacle of the progress of science inexorably requiring the advance of federal power over the individual in social and economic matters, the similar advance of state power so long as it does not conflict with federal, and when it does conflict, the supremacy of federal power. At the same time the same progress has greatly increased the urgency of protecting the rights and freedoms of the Bill of Rights against all governmental invasion. There is little hope that the primary cause of these phenomena will not continue to operate with increasing force. We cannot turn back the calendar, however much we wish it, nor can we retard even for a moment the onward march of science in a nationalistic world. Most of us are going forward to meet the future, with confidence or with resignation according to the spirit of our souls, without cringing before supersonic speed or bending the knee to atomic energy. That is, at any rate, the course which government must follow. Therefore, it seems highly probable that none of the processes set in motion by this fundamental cause have as yet reached their final development. In a contracting world there has so far been no escape from expanding power. But it may be increasingly necessary to limit it by the First Amendment freedoms, in order that power in general may be exercised more democratically, more harmoniously, and more intelligently. Exposed to the freest criticism and circumscribed by the rights of one accused of crime, the whole broad sweep of power may

42. Adamson v. California, 332 U. S. 46, 70-71 (1947): The Fifth, Sixth, and Eighth Amendments were pointedly aimed at confining exercise of power by courts and judges within precise boundaries, particularly in the procedure used for the trial of criminal cases. Past history provided strong reasons for the apprehensions which brought these procedural amendments into being and attest the wisdom of their adoption. For the fears of arbitrary court action sprang largely from the past use of courts in the imposition of criminal punishments to suppress speech, press, and religion. Hence the constitutional limitations of courts' powers were, in the view of the Founders, essential supplements to the First Amendment, which was itself designed to protect the widest scope for all people to believe and to express the most divergent political, religious, and other views.

See his similar suggestion in Feldman v. United States, 322 U. S. 487, 496, 501 502 (1944). 
be exercised fairly and efficiently. There is no efficient exercise of power in the conviction of an innocent man.

One must resort to speculation to determine how the Court has been influenced by the advance of federal power in the parallel development of enforcing liberty against the states. It may be observed, however, that there is at any rate a rather striking relationship in the respective chronologies. The Interstate Commerce Act, ${ }^{43}$ which was the first important exercise by Congress of its power under the commerce clause ${ }^{44}$ came in 1887 . It was ten years later, in 1897, that the Court for the first time held that "liberty," as guaranteed by the Fourteenth Amendment, meant more than freedom from physical restraint of the person. ${ }^{45}$ The great increase in federal power resulting from the Wilson Administration and the First World War was followed, in 1925, by Gitloze v. People of Nere York, which protected against state denial freedom of speech and of the press. The vast enlargement of federal power which has ensued since 1933, due both to the New Deal and the Second World War, may have some relation to the further extensions of liberty which the Court commenced in 1937 and which are still continuing. ${ }^{48}$ There is no direct evidence to establish that the Court has considered the advance of governmental power in connection with the broadening of liberty. But certainly it would be remarkable if it had not.

At the same time, precisely as contemplation of Hitler's Germany had its influence both in the enactment of the flag salute legislation and in the decision ${ }^{47}$ which struck that legislation down, so from the advance of federal power a contrary influence may be drawn. Both Congress and the Court have seemed sometimes to be concerned by the effect upon the states of the wholesale transfer of power from them to the federal government. In many instances Congress has compensated the states for their loss of power by subsidies, as in the case of road construction, social security funds and many other matters,

43. 24 Stat. 379 (1887), 49 U. S. C. $\$ 1$ (1946).

44. See 2 Warren, The Supreare Court in United States History 729 et seq. (1937).

45. Allgeyer v. Louisiana, 165 U. S. 578 (1897). This brought liberty of contract within the liberty protected by the due process clause. The breaking down here of the "physical restraint" conception of liberty made it possible later to bring the First Amendment freedoms within it.

46. In this period the greatest development of the First Amendment freedoms has occurred. The most important decisions are De Jonge v. Oregon, 299 U. S. 353 (1937); Herndon v. Lowry, 301 U. S. 242 (1937); Thornhill v. Alabama, 310 U. S. 88 (1940); Cantwell v. Connecticut, 310 U. S. 296 (1940); Bridges v. California, 314 U. S. 252 (1941); Murdock v. Pennsylvania, 319 U. S. 105 (1943) ; West Virginia State Board of Education v. Barnette, 319 U. S. 624 (1943) ; Craig v. Harney, 331 U. S. 367 (1947) ; Illinois ex rel. McCollum v. Board of Education, 333 U. S. 203 (1948).

47. West Virginia State Board of Education v. Barnette, 319 U. S. 624 (1943). 
these federal "grants-in-aid" in 1947 amounting to nearly $\$ 1,950$,$000,000 . .^{48}$ And the Court, without Congressional action, has itself given to the states rights of taxation never before enjoyed, in one instance overruling a decision which had stood for more than sixty years in order to do so. ${ }^{49}$ Some members of the Court may have felt, perhaps unconsciously, a reluctance (originating in the same concern) to restrict the states' exercise of power over the individual in a field such as the Bill of Rights, where the restriction was not necessary to effect the policies of Congress or the inevitable social and economic regulation. Mr. Chief Justice Chase observed in 1869 that this was an indestructible union of indestructible states. ${ }^{50}$ There is no doubt about the indestructibility of the union; that had already been determined, whether rightly or wrongly, by Appomattox, if not before. And if the result of the War Between The States had been different, one may think that nevertheless the inexorable march of events would have contrived in the end the same unity. But certainly one may be forgiven now for apprehension with regard to the destructibility of the states. This consideration may have contributed, consciously or not, to the reluctance of some members of the Court to enforce the Bill of Rights against the states.

\section{The Infirmity of the Unanimous or Eight-to-one Opinion: The First Amendment Cases}

The struggle to enforce the First Amendment freedoms against the states did not cease with Gitlow v. People of New York; it has continued with little abatement to this day. It has not, however, centered on the inclusion in liberty of the other freedoms, as to which the Gitlow opinion was silent, that inclusion having been accomplished without debate. In the case of the free exercise of religion, it is true that in 1934, three Justices (Cardozo, Brandeis and Stone) were willing to assume the inclusion only "for present purposes"; ${ }^{51}$ and that, in spite of Mr. Justice Sutherland's remark that "'liberty' is a word of wide meaning, and, without more, would have included the various liberties guaranteed by the First Amendment," 52 the Court, in cases involving the distribution of religious literature by Jehovah's Wit-

48. N. Y. Times, Aug. 26, 1948, p. 7, col. 6.

49. Graves v. New York, 306 U. S. 466 (1939), overruling Collector v. Day, 11 Wall. 113 (U. S. 1870). See also McGoldrick v. Berwind-White Coal Mining Co., 309 U. S. 33 (1940); Northwest Airlines, Inc. v. Minnesota, 322 U. S. 292 (1944).

50. Texas v. White, 7 Wall. 700 (U. S. 1868).

51. Hamilton v. University of California, 293 U. S. 245, 265 (1934).

52. Dissenting opinion, Associated Press v. National Labor Relations Board, 301 U. S. 103, 134 (1937). Justices Van Devanter, McReynolds and Butler concurred in this opinion. 
nesses, as late as 1937 refused to consider the abridgment of the free exercise of religion by an ordinance which it then struck down as invading freedom of the press. $^{53}$ But the continuing struggle, al. though it has sometimes had the aspect of a rear-guard action, has been over the scope of the freedoms which are now included in liberty, on whether to interpret them broadly or narrowly. ${ }^{54}$ Unanimous opinions, even including with them eight-to-one opinions, have been infrequent in cases of first impression.

As the tide of liberty for forty years has been an almost steadily advancing one, it is natural that propositions originally advanced in dissenting opinions should tend eventually to become the opinion of the majority, necessitating the overruling of the original holding expressly or-more often-sub silentio. A well-known example of this is Mr. Justice Harlan's famous dissent in Patterson v. Colorado:

I go further and hold that the privileges of free speech and of a free press, belonging to every citizen of the United States, constitute essential parts of every man's liberty, and are protected against violation by that clause of the 14th Amendment forbidding a state to deprive any person of his liberty without due process of law. It is, I think, impossible to conceive of liberty, as secured by the Constitution against hostile action, whether by the nation or by the states, which does not embrace the right to enjoy free speech and the right to have a free press. ${ }^{55}$

The proposition which Mr. Justice Harlan alone ${ }^{56}$ advanced in 1907 was accepted by the Court in $1925^{57}$ and the development of freedom of speech and of the press thereafter was so rapid as to make it possible in 1941 to say that "in a series of opinions as uncompromising as any in its history, this Court has settled that the fullest opportunities for free discussion are implicit in the concept of ordered liberty, and thus, through the Fourteenth Amendment;' protected against attempted invasion by the States." 58

53. Compare Coleman v. Griffin, 302 U. S. 636 (1937), with Lovell v. Griffin, 303 U. S. 444 (1938). In 1939 the Court again avoided holding that the free exercise of religion was protected by the due process clause, placing the decision in Schneider $\mathrm{v}$. Irvington, 308 U. S. 147 (1939), on freedom of the press instead.

54. The cases on the free exercise of religion are collected and given detailed consideration in Rutledge, Religious Liberty and the Fonrtenth Amendment, 9 GA. B. J. 141 (1946).

55. 205 U. S. 454, 465 (1907).

56. He had been auticipated by the state courts in this expansion of liberty. See, e.g., State v. Julow, 129 Mo. 163, 172-173, 31 S. W. 781, 782 (1895), and Marx \& Haas Clothing Co. v. Watson, 168 Mo. 133, 146, 67 S. W. 391,394 (1902), discussed, Green, Liberty Under the Fourteenth Amendment, 27 WASH. U. L. Q. 497, 509 n. 58.

57. Gitlow v. People of New York, supra note 12. As late as 1922 the Court had expressly rejected it. Prudential Insurance Co. v. Cheek, 259 U. S. 530, 538, 543 (1922). (1941).

58. Mr. Justice Frankfurter, in Bridges v. California, 314 U. S. 252, 281-282 
It is therefore not extraordinary that dissenting opinions in this field should often have greater vitality than majority opinions, and be excelled as foundations for the future only by obiter dicta. ${ }^{59}$ What is noteworthy is that unanimous or nearly unanimous opinions should appear to be less dependable as authority than five-to-four, six-to-three, or even seven-to-two opinions. While it should not be overstated, there is an inference that the unanimous opinion, which in the short period of time here considered cannot be undermined simply by a partial change in the composition of the Court, carries within itself the seeds of its own destruction.

It was in 1940 that the Court in Minersville School District v. Gobitis ${ }^{60}$ held that a school board regulation requiring all children to salute the flag and recite a pledge of allegiance was not a deprivation - of religious liberty, in the case of children belonging to Jehovah's Witnesses, who, the Court said, refused to participate, in the conscientious belief that this was forbidden by the Scriptures. From this holding the solitary dissenter was Mr. Justice Stone. In 1943 the decision was overruled, six-to-three, by West Virginia State Board of Education v. Barnette, ${ }^{61}$ its life being thus only three years. This was not so short as that of another decision against Jehovah's Witnesses, Jones v. Opelika, ${ }^{62}$ which was overruled ${ }^{63}$ while it was, in effect, still pending on motion for rehearing; ${ }^{64}$ but the overruling of that five-to-four decision was accomplished by a change in the composition of the Court. The key to the overruling of the flag salute decision was quite different, lying in the fact that Justices Black, Douglas and Murphy had changed their minds ${ }^{65}$ and no longer were willing to carry Mr. Justice Holmes' philosophy of judicial laissez-faire to the point of applying it to legislation invading religious freedom.

Mr. Justice Frankfurter had written for the Court in the Gobitis case; writing now, in the Barnette case, for himself alone, he advanced much beyond this, carrying the doctrine further and stating it more broadly than Mr. Justice Holmes ever did. Even though legislation relates to civil liberties, "our duty of deference" to the legislature "is not less relevant or less exacting." He considered that the Court's

59. See Green, The Bill of Rights, the Fourteenth Amendnent and the Supreme Court, 46 M MCH. L. Rev. 869, 870-1 (1948).

60. 310 U. S. 586 (1940).

61. 319 U. S. 624 (1943).

62. 316 U. S. 584 (1942).

63. By Murdock v. Pennsylvania, 319 U. S. 105 (1943).

64. See Jones v. Opelika, 319 U. S. 103 (1943).

65. In addition, Justices Jackson and Rutledge had replaced Mr. Chief Justice Hughes and Mr. Justice McReynolds. 
"only and very narrow function" in dealing with legislation, "is to determine whether, within the broad grant of authority vested in legislatures, they have exercised a judgment for which reasonable justification can be offered." Even this much prevents "the free play of the democratic process." He thought the essence of the religious freedom guaranteed by the Constitution to be simply: "no religion shall either receive the state's support or incur its hostility"; the individual conscience "cannot restrict community action ... . in matters of community concern, so long as the action is not asserted in a discriminatory way . .." 66

One who is not able to agree with Mr. Justice Frankfurter's conclusion must nevertheless recognize that in profoundness of thought, in power and in clarity, this opinion has seldom been surpassed. It is therefore the more striking that whereas his opinion in the Gobitis case had commanded the concurrence of six members of the Court, ${ }^{67}$ his much more profound opinion in the Barnette case now failed to receive the concurrence of any; two of the former six, Justices Roberts and Reed, preferring to state simply that they adhered to the earlier opinion. ${ }^{68}$ Here may perhaps lie one clue to the infirmity of the unanimous opinion. Presumably it must pay for the support it commands by the acceptance of compromising modifications. And the opinion suggests another consideration. While Mr. Justice Frankfurter expressed the view of the Court more than adequately in the Gobitis case, nevertheless when he wrote as a dissenter, with his back to the wall, his opinion rose to new heights. In this field of the law, at least, it appears that formidable opposition has a strengthening effect upon the opinion.

66. 319 U. S. 624, 646 et seq. (1943). There was evident in Mr. Justice Frankfurter's opinion a disposition to place greater emphasis on the prohibition of the establishment of religion than on the guarantee of the free exercise thereof. Everson v. Board of Education, 330 U. S. 1 (1947), made clear the possibility of conflict which lies latent in these two causes. The Everson case dealt with a situation which Mr. Justice Frankfurter had expressly foreseen in his Barnette opinion (at 660) : a New Jersey school board undertook to reimburse parents for bus fares paid to bring their children to the schools, both public and parochial. Attendance at parochial schools might be considered an exercise of religion; and certainly the state could not prohibit it. Pierce v. Society of Sisters, 268 U. S. 510 (1925). To reimburse parents for the transportation of their children to public schools, but not for transportation to parochial schools, might accordingly be claimed a discrimination against such exercise of religion. On the other hand, the implications of such reimbursement with respect to the establishment of religion are plainly evident. The five-to-four decision that the reimbursement did not violate the prohibition against establishment of religion naturally found Mr. Justice Frankfurter among the dissenters, who seem to have the better of the judicial debate.

67. All but Mr. Justice McReynolds, who concurred in the result, without opinion, and Mr. Justice Stone.

68. It must also be noted that Justices Black and Douglas declined to follow Mr. Justice Jackson, who gave the opinion of the Court, in placing the decision upon invasion of the "freedom of silence," their concurrence in the result being solely upon the free exercise of religion. Mr. Justice Murphy concurred on both grounds. 
It is true that in such cases as the flag salute decisions each Justice must to some extent be affected in his conception of the free exercise of religion, by "his experience and imagination, his hopes and fears, his faith and doubts"; and that the varieties of religious experience may range from the deepest and most profound, to something very much less. This may have some bearing upon the disagreement in the decisions of the 1942 Term with regard to the proselyting of Jehovah's Witnesses, but it can hardly be held accountable for the fragility of the Gobitis opinion. Indeed, the infirmity of the unanimous opinion is shown even more clearly in the unanimous decisions dealing with freedom of expression, so that one must conclude that the infirmity results from the unanimity and not from the subject matter.

In Thornhill v. Alabama, ${ }^{69}$ an eight-to-one decision, ${ }^{70}$ the Court in 1940 struck down as an invasion of free speech, a statute prohibiting picketing. The case, like most of the picketing decisions which followed it, was rightly decided; but the opinion contained language which could hardly have been more unfortunate. The Court for the first time expressed a concept of areas of speech which were within the protection of the First Amendment, necessarily implying that there were other areas which were not. Through Mr. Justice Murphy, it said (with a prolix supporting argument based upon the "importance" of "satisfactory hours and wages and working conditions in industry") :

In the circumstances of our times the dissemination of information concerning the facts of a labor dispute must be regarded as within that area of free discussion that is guaranteed by the Constitution. ${ }^{71}$

As used here, this was preceded by a sentence which to an extent qualified it; ${ }^{72}$. but the qualification, inadequate and subjective though it was, was omitted when the "area" proposition was later repeated or paraphrased. ${ }^{73}$ The expression was not only inherently unsound, but

69. 310 U. S. 88 (1940).

70. Mr. Justice McReynolds dissented without opinion.

71. Id. at 102 .

72. "Freedom of discussion . . . must embrace all issues about which information is needed or appropriate to enable the members of society to cope with the exigencies of their period."

73. In Carlson v. California, 310 U. S. 106, 113 (1940); by Mr. Justice Black, dissenting, in Milk Wagon Drivers Union v. Meadowmoor Dairies, Inc., 312 U. S. 287, 303 (1941) ; by Mr. Justice Douglas, concurring, in Bakery and Pastry Drivers v. Wohl, 315 U. S. 769,776 (1942); by Mr. Justice Black, dissenting, and Mr. Justice Reed, dissenting, in Carpenters \& Joiners Union v. Ritter's Cafe, 315 U. S. 722, 730, 734 (1942) ; and by Mr. Justice Rutledge in Thomas v. Collins, 323 U. S. 516, 532 (1945). Mr. Justice Frankfurter, who has spoken for the Court in all but one of the picketing cases since the Carlson case, has carefully avoided this language. 
inherently dangerous, for placing utterances regarding labor disputes in a preferred position automatically places other speech in either an inferior or an excluded position. The First Amendment protects all speech, and to limit the freedom to speech on such subjects-and in such directions-as a majority of the Court may from time to time regard with favor, is to destroy it. It can hardly be supposed that Mr. Justice Holmes would have accepted this language ;4 $^{74}$ still less that he would have consented to apply it-as the Court subsequently did-to information regarding one side of the dispute only, not both sides. $^{75}$ In 1945, in Thomas v. Collins, ${ }^{76} \mathrm{Mr}$. Justice Jackson, with engaging candor, observed: "But I must admit that in overriding the findings of the Texas court we are applying [to labor] a rule the benefit of which in all its breadth and vigor this Court denies to employers in National Labor Relations Board cases." 77 In the Thomas case Mr. Justice Rutledge repeated the "area" language for the last time; ${ }^{78}$ but at the same time-perhaps to meet Mr. Justice Jackson's observations-in effect negated it by the statement that "the rights of free speech and a free press are not confined to any field of human interest." 79

In addition, it must be observed that the First Amendment does not protect the "dissemination of information" or its "communication," its framers having preferred to say "freedom of speech and of the press," which is by no means so broad. Every act, however divorced from language, communicates and disseminates information, if it can be seen, heard, felt or otherwise discovered. A great deal of information is communicated by knocking a man down, the fact that you do not much like him being only part of this. Since there is often a good deal of action on the picket line, the use of this language in the Thornhill case was particularly unfortunate.

A foreseeable result of the Thornhill concept of protected areas of speech was Valentine v. Chrestensen, ${ }^{80}$ where a unanimous Court,

74. Judge Hutcheson has contrasted the steadiness with which Mr. Justice Holmes maintained his attitude of judicial tolerance of legislative policy with "the Bourbonism and class consciousness" of the Thornhill opinion. Book Review, 30 A. B. A. J. 106107 (1944).

75. When the Court later had to deal with the employer's freedom of speech, in National Labor Relations Board v. Virginia Electric \& Power Co., 314 U. S. 469 (1941), in Virginia Electric \& Power Co. v. National Labor Relations Board, 319 U. S. 533 (1943), and in May Dept. Stores Co. v. National Labor Relations Board, 326 U. S. 376 (1945), it made no reference to the Thornhill "area," and gave no effect whatever to the considerations there relied on.

76. 323 U. S. 516 (1945).

77. $I d$. at 548 .

78. $I d$. at 532 .

79. Id. at 531 .

80. 316 U. S. 52 (1942). 
through Mr. Justice Roberts, upholding a New York ordinance which absolutely prohibited the distribution of advertising matter on the streets, said that, while the streets were "proper places for the exercise of the freedom of communicating information and disseminating opinion," which privilege might not be unduly burdened or proscribed, the Court was "equally clear that the Constitution imposes no such restraint on government as respects purely commercial advertising." The result reached here may be right-there is no way to tell from the opinion; but certainly the reason given for it cannot be. The holding that "commercial advertising" (presumably because of the profit motive of the advertiser) ${ }^{81}$ is wholly outside the protection of the First Amendment could in the long run destroy most newspapers and periodicals of general circulation, by exposing the advertising on which they depend to discriminatory taxation or even outright prohibition. A more fundamental reason why the proposition cannot be maintained is that these freedoms are the right of the listener as well as of the speaker, of the reader as well as of the publisher; and indeed that is the reason why they are protected. The Court should have deferred consideration of the nature of the literature until it struck a balance under the clear and present danger rule, and even then it would be difficult to obtain support for the view that commercial advertising is wholly without social value. ${ }^{82}$

The Court's unanimous opinion in Chaplinsky v. New Hampshire ${ }^{83}$ upheld the conviction of a member of Jehovah's Witnesses for calling the complainant, on a public street, a "Fascist," the Court remarking that "such utterances are no essential part of any exposition of ideas, and are of such slight social value as a step to truth that any benefit that may be derived from them is clearly outweighed by the social interest in order and morality." 84 "Damned Fascist," it ob-

81. In most of the cases where the Court has protected picketing as free speech, the picketing was not by striking employees or former employees of the enterprise picketed. In such cases as American Federation of Labor v. Swing, 312 U. S. 321 (1941), Bakery \& Pastry Drivers v. Wohl, 315 U. S. 769 (1942), and Cafeteria Employees Union v. Angelos, 320 U. S. 293 (1943), the picketing was by a union which represented no employees, but was seeking to "muscle in." Such picketing may be actuated primarily by the profit motive (of the union) as much as any other advertising.

82. The Court has not had to deal with the application of the First Amendment to commercial advertising, since the Valentine decision. In Railway Express Agency, Inc. v. New York, 336 U. S. 106 (1949), a municipal traffic regulation prohibiting the use of advertising vehicles in the streets, but permitting the use of trucks by their owners to advertise their own wares, was upheld against an attack on it as a denial of due process and of the equal protection of the laws; but no mention was made of the First Amendment.

83. 315 U. S. 568 (1942).

84. Id. at 572 . 
served, was an epithet "likely to provoke the average person to retaliation, and therefore cause a breach of the peace." 85 Less than two years later the unanimous opinion in Cafeteria Employees Union $v$. Angelos $^{88}$ held that a labor union which picketed a cafeteria in an attempt to organize it, telling prospective customers that the cafeteria "served bad food," and that by patronizing it "they were aiding the cause of Fascism," could not be enjoined, even though the signs carried and statements made were "knowingly false." The word "Fascist" was characterized as "loose language" that was "part of the conventional give-and-take in our economic and political controversies." 87 In view of the ultimate fate of the Thornhill "area" proposition, it cannot be assumed that the Court still regards the First Amendment as conferring any greater measure of freedom of speech on labor unions than on Jehovah's Witnesses. The opinions are obviously inconsistent, and the Chaplinsky language must be considered to have been modified by Angelos.

In the same way the unanimous opinion in Cox v. New Hampshire ${ }^{88}$ seems, as to the $\$ 300.00$ license fee for a religious parade in the city streets, hopelessly inconsistent with the subsequent five-to-four decision in Murdock $v$. Pennsylvania, ${ }^{80}$ which held that a license tax could not be imposed on the exercise of a privilege granted by the Bill of Rights.

A notable exception is Cantwell $v$. Connecticut, ${ }^{90}$ the nine-tonothing opinion which in 1940 brought the free exercise of religion within the "liberty" which is protected by the Fourteenth Amendment, and upon which the Court has since built a considerable structure. Other unanimous or eight-to-one opinions in this field will be found sound enough when they follow and reflect earlier decisions by a divided Court, the struggle having been abandoned by the losing sidein which case, of course, their authority is simply cumulative. But in the cases of the last nine years, where the question considered by the Court was novel, if the unanimity of the opinions is not quite "the unanimity of the graveyard," ${ }^{91}$ it is, with the exception noted, at least the unanimity of the hospital. It may fairly be suggested that unani-

85. $I d$. at 574 .

86. 320 U. S. 293 (1943).

87. Id. at 295 .

88. 312 U. S. 569 (1941).

89. 319 U. S. 105 (1943).

90. 310 U. S. 296 (1940).

91. Mr. Justice Jackson's expression-in another connection-in West Virginia State Board of Education v. Barnette, 319 U. S. 624, 641 (1943). 
mous opinions on questions of first impression in this most difficult field are not good insurance risks; that they often suffer from what may be regarded, according to the reader's temper, as the faults of unwatched carelessness or of unchecked exuberance; that they may sometimes be feeble because they have not been exposed to and toughened by substantial opposition; and that, on the other hand, occasionally their life-blood is drained away in order to placate each of seven or eight concurrers.

The purpose of written opinions, often required by state constitutions, is to inform not only the litigants, but the legislatures, the executive enforcement officers, the bar, the public and the courts to come, as well, of the reasons for the decisions. The infirmity of the unanimous opinion often defeats this purpose. The superficial unanimity tends to break down when one attempts to build on the opinion thereafter. Such opinions do not delineate clearly the views of the judges, but present a picture which is often blurred or distorted; their apparent clarity may be artificial and unreal. They accordingly may mislead all other courts and all persons who rely upon them.

\section{From Conclusion to Premise: Clear and Present Danger}

We are told by authorities of diverse experience-Mr. Justice Cardozo, Mr. Radin and Signor Calamandrei ${ }^{92}$ - that the course of judicial reasoning is frequently backward, from conclusion to premise. It is a course which (as has been pointed out ${ }^{93}$ ) is familiar to the practicing lawyer, whose client often presents him with a conclusion ready-made, and who must then search for whatever premises can be discovered or developed, to support that conclusion. It is no doubt true also that the judicial practice of taking a vote following the oral argument, leaving the opinion to be written later, is frequently conducive to the inverted process.

When the whole structure is complete in the opinion, it is naturally difficult to detect whether the roof was first erected or the supporting pillars. One would think that Mr. Justice Brandeis must have almost invariably proceeded in the orthodox fashion, from premise to conclusion, and that Mr. Justice Holmes must in some cases have proceeded in this fashion and in others in the reverse; but the fact may have been quite otherwise. For not only is the opinion deceptive, but there can also be dispute as to what is a conclusion and what a

92. Cardozo, The Nature of The Judicial Process 142-177 (1925), quoting Saleilles at 170; Radin, The Trail of the Calf, 32 CoRN. L. Q. 137, 141 (1946) ; CALAMANDREI, Eulogy of Judges 83-85 (Adams \& Phillips trans. 1942).

93. Calamandrei, op. cit. supra note 92 , at 84 . 
premise. One man's premise may be another's conclusion; and every premise which is not an absolute is itself the conclusion of some syllogism, however long forgotten.

In Patterson $v$. Colorado ${ }^{94}$ where a publication was punished as contempt of court, Mr. Justice Holmes appears, on the surface of the opinion, to have arrived at the wrong conclusion by proceeding from wrong premises. In this 1907 opinion, which seems to have escaped the attention of his biographers, he committed the Court-in the face of $\mathrm{Mr}$. Justice Harlan's powerful dissent ${ }^{95}$-to a proposition which was not only an error of law of some magnitude, but which in substance nullified the freedom of the press guaranteed by the First Amendment. He held flatly that the First Amendment did not "prevent the subsequent punishment of such [publications] as may be deemed contrary to the public welfare," that "the preliminary freedom extends as well to the false as to the true; the subsequent punishment may extend as well to the true as to the false. This was the law of criminal libel apart from statute in most cases, if not in all."

Here Mr. Justice Holmes forged the fetters for the press, and did it neatly, in three sentences. For by limiting the freedom to freedom from previous restraints he reduced it to a matter of no practical contemporary value, the federal government and the states having resorted to subsequent punishment rather than to the seventeenth-century method of prior licensing. Relying upon Blackstone, ${ }^{96}$ he ignored wholly such matters as the causes of the American Revolution, the change effected in England itself by Fox's Libel Act and the reasons for that change, and the whole body of law which had invigorated freedom of the press, if not west of the Berkshires, at any rate west of the Alleghenies. ${ }^{97}$ As the Court later said, in a case very much like the Patterson case: "To assume that English common law in this field

94. 205 U. S. 454 (1907).

95. Cf. his 1919 estimate of Mr. Justice Harlan: "Although a man of real power, [Harlan] did not shine either in analysis or generalization and I never troubled myself much when he shied. I used to say that he had a powerful vise the jaws of which couldn't be got nearer than two inches to each other." 2 HoLMEs-Pollock LeTTERs 7-8 (Howe ed. 1941).

96. He cited also a Pennsylvania decision which antedated the First Amendment, and a Massachusetts decision of 1825 which held that the English common law as to seditious libel had not been abrogated by the Massachusetts Constitution. As to the reliance on Blackstone, the Court later said, in Near v. Minnesota, 283 U. S. 697, 714 (1931): "The criticism upon Blackstone's statement has not been because immunity from previous restraint upon publication has not been regarded as deserving of special emphasis, but chiefly because that immunity cannot be deemed to exhaust the conception of the liberty guaranteed by state and federal constitutions."

See also Mr. Justice Sutherland, for a unanimous Court, in Grosjean v. American Press Co., 297 U. S. 233, 245-249 (1936).

97. See Cooley, Constitutional Limitations 603 (7th ed. 1903); $2 \mathrm{id.} 885$ (8th ed. 1927) ; State ex rel. Attorney General v. Circuit Court, 97 Wis. 1, 72 N. W. 193 (1897). For other illustrations of the relatively much greater freedom of the press established west of the Alleghenies long ago by constitutions, legislation or judicial decision see Green, Book Review, 45 CoL. L. Rev. 812, 813 n. 6 (1945). 
became ours is to deny the generally accepted historical belief that 'one of the objects of the Revolution was to get rid of the English common law on liberty of speech and of the press.' More specifically, it is to forget the environment in which the First Amendment was ratified." 98 Even if freedom of the press is not to be interpreted in contemporary terms ${ }^{99}$ to interpret it in terms of 1765 rather than of $1789-1792$ was to ignore the tidal wave of liberty which in this quarter of a century rose more rapidly than ever before or since, and which carried on its crest freedom of the press.

It is, however, possible that this opinion may have gone from conclusion to premise, for Mr. Justice Holmes' conversion to profound attachment to freedom of expression did not come until much later; ${ }^{100}$ it may be taken to have occurred in 1919, and to have coincided roughly with the advent of Mr. Justice Brandeis' influence. Mr. Justice Holmes never expressly recanted the Patterson holding-the most that can be found are two not entirely ingenuous sentences in $1919 ;{ }^{101}$

98. Bridges v. California, 314 U. S. 252, 264 (1941).

99. As to which, cf. Mr. Justice Holmes, in Missouri v. Holland, 252 U. S. 416, 433 (1920): ". . . when we are dealing with words that also are a constituent act, like the Constitution of the United States, we must realize that they have called into life a being the development of which could not have been foreseen completely by the most gifted of its begetters. It was enough for them to realize or to hope that they had created an organism; it has taken a century and has cost their successors much sweat and blood to prove that they created a nation. The case before us must be considered in the light of our whole experience, and not merely in that of what was said a hundred years ago."

613 (1942).

See also Radin, Freedom of Speech and Contempt of Court, 36 ILL. L. REv. 599,

100. Cf. such earlier opinions as that in Commonwealth v. Davis, 162 Mass. 510 , 39 N. E. 113 (1895), where he upheld an ordinance prohibiting speaking on Boston Common without a permit. This has, of course, been invalidated by the decisions of the Supreme Court in the last ten years, as was recently recognized in Commonwealth v. Gilfedder, 321 Mass. 335, 73 N. E. 2d 241 (1947). See also Lerner, The Mind and Faitr of Justice Holmes 106, 289-291 (1943).

One recalls also Mr. Justice Holmes' famous statement in McAuliffe v. New Bedford, 155 Mass. 216, 220, 29 N. E. 517 (1892):

The petitioner may have a constitutional right to talk politics, but he has no constitutional right to be a policeman. There are few employments for hire in which the servant does not agree to suspend his constitutional right of free speech, as well as of idleness, by the implied terms of the contract. The servant cannot complain, as he takes the employment on the terms which are offered him.

This has recently been criticized as "extraordinarily bad contract law," since a contract not to exercise political rights in a democracy is void because contrary to public policy. See Wormuth, The Hatch Act Cases, 1 WESTERN PoL. Q. 165, 171172 (1948).

101. (1) In Schenck v. United States, 249 U. S. 47, 51-52 (1918), he said: "It well may be that the prohibition of laws abridging the freedom of speech is not confined to previous restraints, although to prevent them may have been the main purpose, as intimated in Patterson v. Colorado." Mr. Justice Frankfurter has recently observed that here "Mr. Justice Holmes referred to his opinion in the Patterson case, and not with disapproval." Craig v. Harney, 331 U. S. 367, 389 (1947).

(2) Dissenting in Abrams v. United States, 250 U. S. 616, 630 (1919), he said: "I wholly disagree with the argument of the government that the First Amendment left the common law as to seditious libel in force." This cool repudiation of his sentence in the Patterson opinion (quoted in the text) required some hardihood. 
but in two dissenting opinions ${ }^{102}$ repudiation of the doctrine was implicit; and he concurred in Near $v$. Minnesota, ${ }^{103}$ which discredited it. His defense of freedom of speech and of the press in three classic opinions-in 1919 in Abrams v. United States, ${ }^{104}$ in 1925 in Gitlow v. People of New York, ${ }^{105}$ and in 1929 in United States v. Schwim$m e r^{106}$ - with words like a sword and passages that cannot be forgotten, much more than atoned for Patterson v. Colorado. An even greater service to the First Amendment freedoms lay in his invention of the clear and present danger rule.

This occurred in 1919, in Schenck $v$. United States, ${ }^{107}$ the case in which $\mathrm{Mr}$. Justice Holmes commenced the withdrawal from the Patterson holding. Here one thinks that his process must certainly have been to arrive at his conclusion first. Laying down the test for abridgment of freedom of speech and of the press, he said (as dictum, for the conviction was affirmed) :

The question in every case is whether the words used are used in such circumstances and are of such a nature as to create a clear and present danger that they will bring about the substantive evils that Congress has a right to prevent. It is a question of proximity and degree.

For this proposition there was no premise given, and one would have been difficult to find. ${ }^{108}$

The rule thus invoked from the skies was ignored by Mr. Justice Holmes in two opinions ${ }^{100}$ the following week, but eight months later, dissenting in the Abrams case, he returned to it, saying:

102. Abrams v. United States, 250 U. S. 616, 624 (1919); Gitlow v. People of New York, 268 U. S. 652, 672 (1925). In addition, his concurrence in Mr. Justice Brandeis' dissents in Schaefer v. United States, 251 U. S. 466, 482 (1920); Pierce v. United States, 252 U. S. 239, 253 (1920); the latter's concurring opinion in Whitney v. California, 274 U. S. 357,372 (1927); and in the Court's opinions in Fiske v. Kansas, 274 U. S. 380 (1927), and Stromberg v. California, 283 U. S. 359 (1931), should be noted in this connection.

103. 283 U. S. 697 (1931).

104. 250 U. S. 616, 624 (1919) (dissenting opinion).

105. 268 U. S. 652, 672 (1925) (dissenting opinion).

106. 279 U. S. 644,653 (1929) (dissenting opinion).

107. 249 U. S. $47^{\prime}(1919)$.

108. There is persuasive evidence that he derived it from a test for the degree of proximity to the completed crime, required for a common-law attempt, which he had developed over a long period of time. See Hall, The Substantive Laze of Crimes, 18871936, 50 HARv. L. REV. 616, 621 n. 20 (1937): "The development of this doctrine in Mr. Justice Holmes' mind may be traced through nearly 40 years. It is suggested in Holmes, THE COMMON LAW (1881) 68-69, and was applied while he was on the Supreme Judicial Court of Massachusetts in Commonwealth v. Kennedy, 170 Mass. 18, 48 N. E. 770 (1897), and Commonwealth v. Peaslee, 177 Mass. 267, 59 N. E. 55 (1901). It is reiterated in Swift \& Co. v. United States, 196 U. S. 375 (1905), "where a 'dangerous probability' that the criminal result will happen is required for an attempt conviction."

109. Frohwerk v. United States, 249 U. S. 204 (1919) ; Debs v. United States, 249 U. S. 211 (1919). The Debs opinion (pp. 215 and 216) contained some expressions inconsistent with clear and present danger. 
. . . we should be eternally vigilant against attempts to check the expression of opinions that we loathe and believe to be fraught with death, unless they so imminently threaten immediate interference with the lawful and pressing purposes of the law that an immediate check is required to save the country. ${ }^{110}$

Mr. Justice Brandeis, apparently realizing at once the full possibilities of the new rule, seized on it and by his persistent advocacy of it kept it alive. ${ }^{111}$ In the Gitlow case, ${ }^{112} \mathrm{Mr}$. Justice Holmes, reluctantly acquiescing in the inclusion of freedom of speech and of the press in the liberty guaranteed by the due process clause against state invasion, again returned to clear and present danger; and in $1927 \mathrm{Mr}$. Justice Brandeis, concurring (with Mr. Justice Holmes) in Whitney v. California, ${ }^{113}$ carried the rule to its highest point of development. ${ }^{114}$ This was the last case in which either Mr. Justice Holmes or Mr. Justice Brandeis spoke of clear and present danger, but Mr. Justice Brandeis was one of the majority of the Court which in 1937 finally accepted it, although in incomplete terms. ${ }^{115}$

Commencing with the Thornhill case ${ }^{116}$ in 1940, clear and present danger was frequently applied by the Court. There was an irreconcilable conflict between it and the principle of deference to the legislature unless its action was wholly without foundation, of not permitting "the use of the Fourteenth Amendment beyond the absolute compulsion of its words to prevent the making of social experiments that an important part of the community desires," which Mr. Justice Holmes had elaborated skillfully and (in the end) successfully, in the liberty of contract cases, ${ }^{117}$ if this principle was applied to abridgment

110. Abrams v. United States, 250 U. S. 616, 630 (1919).

111. In dissenting opinions in Schaefer v. United States, 251 U. S. 466,482 (1920); Pierce v. United States, 252 U. S. 239, 253 (1920); and Gilbert v. Minnesota, 254 U. S. 325, 334 (1920). In the first two of these Mr. Justice Holmes concurred, but not in the Gilbert opinion, in which Mr. Justice Brandeis urged the expansion of liberty which was made five years later in the Gitlow case. opinion).

112. See Gitlow v. People of New York, 268 U. S. 652, 672 (1925) (dissenting

113. 274 U. S. 357,372 (1927).

114. The development of the rule is given detailed consideration in Green, Liberty Under the Fourteenth Amendment, 27 WASE. U. I. Q. 497, 539-560 (1942).

115. Herndon v. Lowry, 301 U. S. 242 (1937). In an earlier phase of this case, Mr. Justice Cardozo, dissenting (with Justices Brandeis and Stone) had urged clear and present danger. Herndon v. Georgia, 295 U. S. 441, 446 (1935).

116. Thornhill v. Alabama, 310 U. S. 88 (1940).

117. E. g., Lochner v. New York, 198 U. S. 45 (1905) ; Adair v. United States, 208 U. S. 161 (1908); Coppage v. Kansas, 236 U. S. 1 (1915) ; Truax v. Corrigan, 257 U. S. 312 (1921). Mr. Justice Holmes' dissents in these cases did not urge that the legislation struck down was desirable; on the contrary, if the statute in the Coppage case had, instead of prohibiting "yellow dog" contracts, required them, his philosophy apparently would have demanded that it be equally upheld. Nor did he oppose the inclusion of "liberty of contract" in the "liberty" guaranteed by the due process clauses, but simply sought to restrict its scope. In his first opinion in the Court, Mr. Justice Holmes had conceded that liberty of contract was protected by the Fourteenth Amendment. Otis v. Parker, 187 U. S. 606 (1903). 
of freedom of expression. Yet the Court, from 1940 on, was firmly committed to both concepts.

Deference to the legislature had produced the first flag salute decision, ${ }^{118}$ but direct conflict with clear and present danger did not arise, because the sole dissenter, Mr. Justice Stone, neither there nor in any other of his opinions ever advocated that rule. ${ }^{119}$ At the 1941 term, when the influence of Mr. Justice Holmes on the whole Court was at its peak, the direct clash occurred. In Bridges $v$. California, ${ }^{120}$ the appeal from Holmes to Holmes (or perhaps one should say from the pre-1919 Holmes to the post-1919 Holmes plus Brandeis) was made directly; and his most devoted disciple, Mr. Justice Frankfurter, speaking of clear and present danger for the first time, was driven to say that the Constitution does not "require replacement of an historic text by a phrase which first gained currency on March 3, 1919." 121 The influence now exerted on both sides of the struggle was made clear by the candid statement of Justices Black and Douglas in the second flag salute case, a little later: ${ }^{122}$

Reluctance to make the Federal Constitution a rigid bar against State regulation of conduct thought inimical to the public welfare was the controlling influence which moved us to consent to the Gobitis decision. Long reflection convinced us that although the principle is sound, its application in the particular case was wrong. ${ }^{123}$

Clear and present danger was of course an answer to $\mathrm{Mr}$. Justice Frankfurter's opinion in the Barnette case. ${ }^{124}$ There were other answers. As Mr. Justice Jackson observed, the First Amendment is in terms directed against the legislature ("Congress shall make no law". . .) ; ${ }^{125}$ it was intended to interfere with the "democratic

118. Minersville School District v. Gobitis, 310 U. S. 586 (1940).

119. His silence as to it remained unbroken to his death. He had earlier said, in United States v. Carolene Products Co., 304 U. S. 144, 152 n. 4 (1938): "There may be narrower scope for operation of the presumption of constitutionality when legislation appears on its face to be within a specific prohibition of the Constitution, such as those of the first ten amendments, which are deemed equally specific when held to be embraced within the Fourteenth." In the Gobitis case he said that the legislation must receive "careful scrutiny."

120. 314 U. S. 252 (1941). Mr. Radin has admirably appraised the conflicting interests here, in Freedom of Speech and Contempt of Court, 36 ILL. L. REv. 599 (1942).

121. Id. at 295 (dissenting opinion).

122. This was preceded by a similar statement in the dissenting opinion of Justices Black, Douglas and Murphy at the 1941 Term. Jones v. Opelika, 316 U. S. 584, 623624 (1942).

123. West Virginia State Board of Education v. Barnette, 319 U. S. 624, 643 (1943) (concurring opinion).

124. See pp. 622-623 supra.

125. Madison was particularly emphatic as to the direction of the Amendment against legislative restraints. See Near v. Minnesota, 283 U. S. 697, 714 (1931). 
process," being based on the sad knowledge that to an unpopular minority an unchecked democracy may be more tyrannical than the tyrant. The experiments in which Mr. Justice Holmes felt the states should be free to engage were social or economic, not "experiments" (essentially counter-experimental) in abridging the First Amendment freedoms. ${ }^{126}$ In any case the states were no longer the laboratories for social and economic experiments, these being now usually held to invade the federal power under the commerce clause. ${ }^{127}$ Only six weeks before the Gobitis decision, Mr. Justice Frankfurter had concurred in the decisions ${ }^{128}$ which struck down, without a hint of deference to the legislatures, statutes restricting labor picketing. Where was the difference? It was suggested that that legislation interfered with the political processes. But every utterance, every refusal to salute the flag, is an influence, "every idea is an incitement"; and every utterance which is punished is necessarily in a field which is now political, or the punitive legislation would not be enacted. The vast expansion of governmental power, referred to above, has brought within its orbit almost every subject of concern to mankind. The "free play of the democratic process" is now far wider than before. Legislation is the result of politics; and politics-like its extension, warhas tended to become total. Greater scope for the First Amendment freedoms seems to be a necessary corollary.

In the Bridges case, Mr. Justice Black, for the five-to-four majority, presented clear and present danger as "a working principle that the substantive evil must be extremely serious and the degree of imminence extremely high before utterance can be punished"; adding that even this did not "mark the furthermost constitutional boundaries of protected expression." ${ }^{129}$ The rule was thus brought almost to the peak of development reached by Mr. Justice Brandeis fourteen years earlier. ${ }^{130}$ It was subsequently carried to its logical conclusion by $\mathrm{Mr}$. Justice Murphy, dissenting in Prince v. Massachusetts:

. . . the human freedoms enumerated in the First Amendment and carried over into the Fourteenth Amendment are to be presumed to be invulnerable and any attempt to sweep away those

126. See Frankfurter, Mr. Justice Holmes and the Supreme Court 51 (1938): "These enduring liberties . . were ... specifically enshrined in the Bill of Rights. . . . Because these civil liberties were explicitly safeguarded in the Constitution, or conceived to be basic to any notion of the liberty guaranteed by the Fourteenth Amendment, Mr. Justice Holmes was far more ready to find legislative invasion in this field than in the area of debatable economic reform."

127. See pp. 614-615 supra.

128. Thornhill v. Alabama, 310 U. S. 88 (1940) ; Carlson v. California, 310 U. S. $106(1940)$.

129. Bridges v. California, 314 U. S. 252, 263 (1941).

130. In his concurring opinion in Whitney v. California, 274 U. S. 357, 372 (1927). In the Bridges case the Court quoted and applied this opinion for the first time. 
freedoms is prima facie invalid. It follows that any restriction or prohibition must be justified by those who deny that the freedoms have been unlawfully invaded. The burden was therefore on the state of Massachusetts to prove the reasonableness and necessity . . ${ }^{131}$

This is of course rather more than denying the presumption of constitutionality to legislation invading the First Amendment freedoms; ${ }^{132}$ it actually inverts the presumption. While that result has seemed implicit in the rule, it must be observed that it cannot yet be taken as established. A considerable majority of the present Court have committed themselves to clear and present danger, but its only articulate critic has continued the attack begun in the Bridges case. When in 1946 the rule as stated there was applied again in a contempt case, Mr. Justice Frankfurter, concurring, sought to hold clear and present danger to the terms of its infancy (the 1919-1920 opinions). He urged that it "was never used by Mr. Justice Holmes to express a technical legal doctrine or to convey a formula for adjudicating cases," but that it was "a literary phrase not to be distorted by being taken from its context." 133 A year later, dissenting in Craig $v$. Harney, ${ }^{134}$ he returned to the attack. ${ }^{135}$ And recently, when in Kovacs v. Cooper ${ }^{136} \mathrm{Mr}$. Justice Reed (in an opinion in which $\mathrm{Mr}$. Chief Justice Vinson and Mr. Justice Burton concurred) referred again to "the preferred position of freedom of speech," Mr. Justice Frankfurter, in a concurring opinion, observed that this phrase "had uncritically crept into some recent opinions of this Court." $\mathrm{He}$ thought it "a mischievous phrase, if it carries the thought, which it may subtly imply, that any law touching communication is infected with presumptive invalidity." The phrase was "mischievous because it radiates a constitutional doctrine without avowing it." He then reviewed the earlier decisions, and urged that "the claim that any legislation is presumptively unconstitutional which touches the field of the First Amendment and the Fourteenth Amendment, in so far as the latter's concept of 'liberty' contains what is specifically protected

131. 321 U. S. 158, 173 (1944).

132. As to the special status of such legislation, see Note, Inseparability in Application of Statutes Impairing Civil Liberties, 61 HARV. L. REV. 1208 (1948).

133. Pennekamp v. Florida, 328 U. S. 331, 353 (1946).

134. 331 U. S. 367,384 (1947).

135. ". . . 'clear and present danger' becomes merely a phrase for covering up a novel, iron constitutional doctrine. Hereafter the States cannot deal with direct attempts to influence the disposition of a pending controversy by a summary proceeding, except when the misbehavior physically prevents proceedings from going on in court, or occurs in its immediate proximity. Only the pungent pen of Mr. Justice Holmes could adequately comment on such a perversion of the purpose of his phrase." 331 U. S. 367, 391 (1947).

136. 336 U. S. 77 (1949). 
by the First, has never commended itself to a majority of this Court." ${ }^{137}$ To this Mr. Justice Rutledge retorted that he thought Mr. Justice Frankfurter "demonstrates the conclusion opposite to that which he draws, namely, that the First Amendment guaranties of the freedoms of speech, press, assembly and religion occupy preferred position not only in the Bill of Rights but also in the repeated decisions of this Court." 138

Accepting this conclusion as valid (although still subject to most vigorous attack), clear and present danger may perhaps now be said to require that in the balancing of interests there must be placed in the scales, against the social value of the governmental abridgment, a heavy (and uniform) weight representing the absolute value of the freedom, apart from and in addition to the Court's estimate of the social value of the utterance in the particular case.

Thus interpreted and applied, the rule appears to weight the scales in favor of the freedom. But even this formula may be deceptive, for the amount of weighting is not determined. It must also be remembered that, while "clear," "present," "imminent," "serious," "substantial" and the like are all words of emphasis, the future tense remains implicit in the word "danger." Clear and present danger modifield the old rule of "dangerous tendency" by adding a different emphasis; but it is still essentially a subjective test, as Mr. Justice Frankfurter pointed out in the Bridges case. Indeed, the Court is now required to appraise, with no fixed objective standard, not only the danger and the evil, but the social value of the utterance. In "a question of degree" emphasis is important; but it may not be enough. While clear and present danger has now become a formidable weapon for the defense of the First Amendment freedoms, it seems likely to remain formidable only so long as it is wielded by a willing arm. ${ }^{132}$

\section{The DeVelopment of Liberty}

As the broad outlines of liberty have begun to take shape, with the blocking in, one by one, from 1925 to 1947, of all the First Amend-

137. Id. at 455. Amongst others, he quoted the statement on clear and present danger in Thomas v. Collins, 323 U. S. 516, 530 (1945), which he thought "perhaps the strongest language dealing with the constitutional aspect of legislation touching utterance," and observed that "this was the opinion of only four members of the Court."

$\mathrm{He}$ pointed out that "Mr. Justice Holmes was far more ready to find legislative invasion where free inquiry was involved than in the debatable area of economics," and that "the objection to summarizing this line of thought by the phrase "the preferred position of freedom of speech' is that it expresses a complicated process of constitutional adjudication by a deceptive formula."

138. Id. at 463 .

139. Clear and present danger is considered in some detail in Green, Liberty Under the Fourteenth Amendment, 27 WASH. U. L. Q. 497, 539-562 (1942). 
ment freedoms, it becomes possible to view the result in perspective. One may also, with less assurance, hazard some speculation regarding the future. If in the decisions the steady surge of liberty seems sometimes to withdraw, one observes that it has usually returned unabated, indeed with increased force. Such curious authoritarian islands as Prince v. Massachusetts ${ }^{140}$ (where a majority of the Court appeared to consider that the free exercise of religion was guaranteed to adults only) and Valentine v. Chrestensen ${ }^{141}$ seem hardly likely to remain, if the Court is afforded opportunities for overruling the decisions.

The recent expansion of liberty to include the prohibition of the establishment of religion seems fairly certain to bring with it further development. It may possibly follow from Illinois ex rel. McCollum v. Board of Education ${ }^{142}$ that the days of the churches' state-granted tax exemption are numbered. Moreover, the latent possibility of conflict between this prohibition and the First Amendment's immediately following guarantee of the free exercise of religion became evident in Everson v. Board of Education; ${ }^{143}$ and the Court may very well encounter some difficulties in working out an accommodation between these two.

The measure of these freedoms is clear and present danger. It seems evident that this rule has not yet attained its final form. Nor has the Court applied the rule either as widely, ${ }^{144}$ or as uniformly, ${ }^{145}$ as it could with consistence.

The struggle to protect the rights of one suspected, accused or convicted of crime, against state deprivation, ${ }^{146}$ has been perhaps more violent and certainly less victorious than the struggle over the First Amendment freedoms. Two of the rights guaranteed by the Sixth Amendment-the rights to notice of the nature and cause of the accusation, and to trial by an impartial tribunal-had received protection as essential parts of procedural due process ${ }^{147}$ long before Gitlow $v$.

140. 321 U. S. 158 (1944). See Green, 43 MICH. L. Rev. 437, $442-449$ (1944).

141. 316 U. S. 52 (1942). The case is discussed pp. 625-626 supra.

142. 333 U. S. 203 (1948).

143. 330 U. S. 1 (1947). See note 66 supra.

144. The rule has been applied only to outright suppression of the First Amendment freedoms, not to the licensing, taxing or otherwise burdening of them, even though in some of these cases the restraint has appeared to amount in effect to an absolute prohibition. See, e. g., Cox v. New Hampshire, 312 U. S. 569 (1941). Such cases, although they require one additional appraisal (the extent of the restraint) seem capable of being fitted into the rule.

145. See, e. g., United Public Workers v. Mitchell, 330 U. S. 75 (1947), criticized in Wormuth, The Hatch Act Cases, 1 WesterN Poz. Q. 165, 168 (1948).

146. See Green, The Bill of Rights, the Fourteenth Amendment and the Supreme Court, 46 MicH. L. Rev. 869 (1948) for a survey of this.

147. See Holden v. Hardy, 169 U. S. 366, 389-390 (1898). 
People of New York 148 had enlarged "liberty" to include freedom of speech and of the press. Following the Gitlow case, the Court in 1932 held that the right to have "the assistance of counsel," also guaranteed by the Sixth Amendment, was protected against state denial. ${ }^{149}$ The decision was based in part upon the recent enlargement of liberty; and in 1937 the Court said that the right to counsel had "been found to be implicit in the concept of ordered liberty." 150 Of a third such right, that of confrontation with witnesses, the Court had said in 1934 that "for present purposes, we assume that the privilege is re-enforced by the Fourteenth Amendment, though this has not been squarely held"; but the four dissenters there had replied sharply: "It is not a matter of assumption but a certainty that the Fourteenth Amendment guarantees the observance of" this right. ${ }^{151}$ And, commencing in 1936, in the confession cases, the Court had developed a rule, which, as stated in Lisenba $v$. California, ${ }^{152}$ did not sound far removed, if removed at all, from the privilege against self-incrimination.

The progress of these rights was arrested by the turning against them of the fair trial rule (which the Court had simultaneously developed) in Betts $v$. Brady, ${ }^{153}$ in 1942 . The right to appointment of counsel, which earlier decisions had seemed to establish, was there held not to be, historically, a part of due process, and to be confined to cases where its denial would be lacking in "fundamental fairness, shocking to the universal sense of justice." This was "to be tested by an appraisal of the totality of facts in a given case," for what in one setting might be so lacking in another might be the reverse. ${ }^{164}$ In Adamson v. Califormia, ${ }^{155}$ in 1947, the Court made use of the fair trial rule as a substitute for the privilege against self-incrimination guaranteed by the Fifth Amendment, holding that deprivation of the privilege was not necessarily "unfair." Here this phase of the conflict between state power and the Bill of Rights reached its highest point, the four dissenters-Justices Black, Douglas, Murphy and Rutledgeurging that the Bill of Rights was carried over in its entirety into the privileges or immunities clause of the Fourteenth Amendment. In two other cases decided the same day, on right to counsel, Foster

148. 268 U. S. 652 (1925).

149. Powell v. Alabama, 287 U. S. 45 (1932).

150. Palko v. Connecticut, 302 U. S. 319, 325 (1937).

151. Snyder v. Massachusetts, 291 U. S. 97, 131 (1934).

152. 314 U. S. 219, 237 (1941). Mr. Justice Roberts, for the Court, said (as dictum): "The concept of due process would void a trial in which by threats or promises . . . a defendant was induced to testify against himself."

153. 316 U. S. 455 (1942).

154. Id. at 462.

155. 332 U. S. 46 (1947). 
v. Illinois ${ }^{156}$ and Gayes v. New York, ${ }^{157}$ the Court divided in the same way, Mr. Justice Black, for the four dissenters, protesting in the Foster case that the Court now "waters down the Bill of Rights guarantee to counsel" so as "to make it compatible with the Court's standards of decency and a fair trial" as it had in the Adamson case watered down the privilege against self-incrimination. "We cannot know," he said, "what Bill of Rights provision will next be attenuated by the Court."

It is significant that in these decisions the inclusion of the Bill of Rights in toto in the shelter of the Fourteenth Amendment commanded four votes. It is improbable that the fair trial rule can contain much longer the rising tide of liberty, which, since Betts $v$. Brady, it has been used to dam and divert. ${ }^{158}$ The rule itself is open to many objections, the most serious being that it substitutes subjective and emotional judgment, unrestrained by any standard-the particular notions of the particular justice in the particular case-for the precise and inflexible guarantees of the Bill of Rights. On the other hand, while the history of the privileges or immunities clause supports inclusion in it of the entire Bill of Rights, there are certain rights ${ }^{159}$ for whose inclusion there is not much to be said.

It is the due process clause which makes a selective process available. As far as inclusion in "due process" itself goes, while the privilege against self-incrimination is, one thinks, historically entitled to such inclusion, the right to assistance of counsel presents greater difficulty, as Betts v. Brady suggests. A wiser course would seem to be to follow in the path of the First Amendment freedoms, to consider the rights, one by one as they come to the Court, each on its own merits, as to their claims to be an essential part of liberty. It is difficult, in Mr. Justice Harlan's language, to conceive of liberty, as secured by the Fourteenth Amendment against hostile action by the states, which does not embrace at least some of these rights.

So considered, and having some regard also to the incidence of the presentation to the Court of claims of state deprivation, it may be suggested that the right to counsel, the privilege against selfincrimination, the Fourth Amendment's right of security against unreasonable searches and seizures, the Fifth Amendment's right against

156. 332 U. S. 134 (1947).

157. 332 U. S. 145 (1947).

158. The judicial debate of the Adamson case was recently renewed by Mr. Justice Rutledge in Re Oliver, 333 U. S. 257 (1948).

159. The Fifth Amendment's requirement of grand jury indictment in the case of "a capital, or otherwise infamous crime" and the Seventh Amendment's guarantee of trial by jury in civil cases, where the "value in controversy" exceeds twenty dollars. 
double jeopardy, and the Eighth Amendment's prohibition of cruel and unusual punishment, might reasonably be held essential elements of liberty. This course seems to present little risk of upsetting the balance between federal and state power, which is apparently undisturbed by the far more powerful and frequent onslaughts of the commerce clause. ${ }^{160}$

Whether this course is followed, or another, and whatever the eccentricities of the judicial process, the continuing progress of science, with the inevitable results of that progress, seem to make it certain that the final development of liberty has not yet been reached.

160. See pp. 613-615 supra. 